\title{
20. COCCOLITH STRATIGRAPHY, TROPICAL EASTERN PACIFIC OCEAN, DEEP SEA DRILLING PROJECT LEG 54
}

\author{
David Bukry, United States Geological Survey, Scripps Institution of Oceanography, La Jolla, California
}

\section{INTRODUCTION}

Upper Pliocene and Quaternary coccolith assemblages are generally abundant and moderately etched in the short sediment sections cored during Leg 54. Sites 424 and 425 are in hydrothermal areas on the flanks of the Galapagos spreading center east of the Galapagos Islands and just north of the Equator; the remaining Sites 419 through 429 lie within a small area near the junction of the Siqueiros fracture zone and the East Pacific Rise crest (Figure 1). The 144 samples studied from 103 cores ( $461 \mathrm{~m}$ of sediment were recovered) were zoned (Figure 2) according to Bukry (1975). The depth and correlation for the basal coccolith sample and the underlying basalt with magnetic age estimate are tabulated for easy reference (Table 1).

\section{COCCOLITH PLIOCENE/ PLEISTOCENE BOUNDARY}

Because of the tropical location of Leg 54 sites, the abrupt reduction of Discoaster brouweri atop the Cyclococcolithina macintyrei Subzone was used to correlate the Pliocene/Pleistocene boundary (Bukry, 1974). Cyclococcolithina macintyrei persists into the lower Pleistocene Crenalithus doronicoides Zone.

Krasheninnikov (this volume) noted that the foraminifer Globorotalia truncatulinoides was unreliable for correlation in the Leg 54 area; he, therefore, used the disappearance of rare Globigerinoides obliquus extremus to identify the Pliocene/Pleistocene boundary. These coccolith and foraminifer criteria yielded the following boundary levels:

$$
\begin{aligned}
& \text { Site 419: Coccolith: Sample 5-2, 123-125 cm/ } \\
& \text { Sample 5-3, 123-125 cm } \\
& \text { Foraminifer: Sample 5-3, 38-40 cm/ } \\
& \text { Sample 5-4, 39-41 cm } \\
& \text { Site 420: Coccolith: Sample 9, CC?/ } \\
& \text { Sample 10-2, 123-125 cm } \\
& \text { Foraminifer: Sample 10-6, 40-42 cm/ } \\
& \text { Sample 12-3, } 40-42 \mathrm{~cm}
\end{aligned}
$$

Recently, Bizon and Müller (1978) showed that Globigerinoides obliquus and Cyclococcolithina macintyrei became extinct in the Mediterranean virtually simultaneously and proposed their use as guide species for the Pliocene/Pleistocene boundary in this region. Application of these criteria to Site 420 suggests that the last $G$. obliquus extremus in Section 420-12-6 is a preservational top, because $C$. macintyrei and $D$. brouweri persist through Cores 9 to 12 . Alternatively, the cause of the divergence in range might be ecologic.
Establishing consistent criteria to identify the Pliocene/Pleistocene boundary prompted Haq et al. (1977) to select a 1.6-m.y. level just above the Olduvai polarity event. They proposed this level could be identified by overlapping biostratigraphic criteria: (1) Between the first Gephyrocapsa caribbeanica (1.62 m.y.) and the first $G$. oceanica (1.57 m.y.); (2) Above the last Discoaster brouweri (1.64 to 1.8 m.y., ecologically controlled), with $D$. triradiatus often common near the top (Bukry, 1971); (3) At the last Globigerinoides obliquus atop the Olduvai event. Although Haq et al. (1977) did not mention Cyclococcolithina macintyrei, from the history of the species (Bukry and Bramlette, 1969), from its Mediterranean connection to G. obliquus (Bizon and Müller, 1978), and from its estimated tropical extinction age of 1.5 m.y. (Gartner, 1977), we may conclude that it, too, could be used to help bracket the boundary. Because identifications of Gephyrocapsa species are clearly incompatible among different workers (compare the taxonomy and ranges in Bukry, 1973; Hay and Beaudry, 1973; Gartner, 1977; Nishida, 1977; and Haq et al., 1977; with Site 420, this chapter), the use of easily identified $C$. macintyrei and $D$. brouweri as guides to the boundary interval is re-emphasized (Figures 3 and 4).

\section{SIGNIFICANCE OF COCCOLITHUS PELAGICUS (WALLICH) IN THE TROPICAL EASTERN PACIFIC}

Most Leg 54 sites were continuously cored and three upper Pliocene and Quaternary sections were recovered. Inspection of the range and abundance of the coolwater guide species (McIntyre et al., 1970) Coccolithus pelagicus shows agreement between paleoecological trends of Leg 54 and Legs 16 and 34 in the tropical eastern Pacific. There is a general trend of diminution of coolwater guide species and an increase in warm-water guides among coccolithophores and silicoflagellates upwards from the upper Pliocene through the Quaternary. Both the silicoflagellate genus Distephanus and the coccolithophore $C$. pelagicus show this reduction in numbers (Bukry and Foster, 1973; Bukry, 1976).

The diminution and disappearance of Coccolithus pelagicus from the tropical eastern Pacific is not uniform (Figure 5). C. pelagicus disappeared at the northern Siqueiros sites earlier than at the equatorial Galapagos sites. Being a cool-water species, presently limited by the $14^{\circ} \mathrm{C}$ isotherm (McIntyre et al., 1970), this seeming paradox in the distribution of $C$. pelagicus must be due to the cool-water regime associated with the northern Peru Current or with another cool near-surface current in the Galapagos area bringing cool water into the 


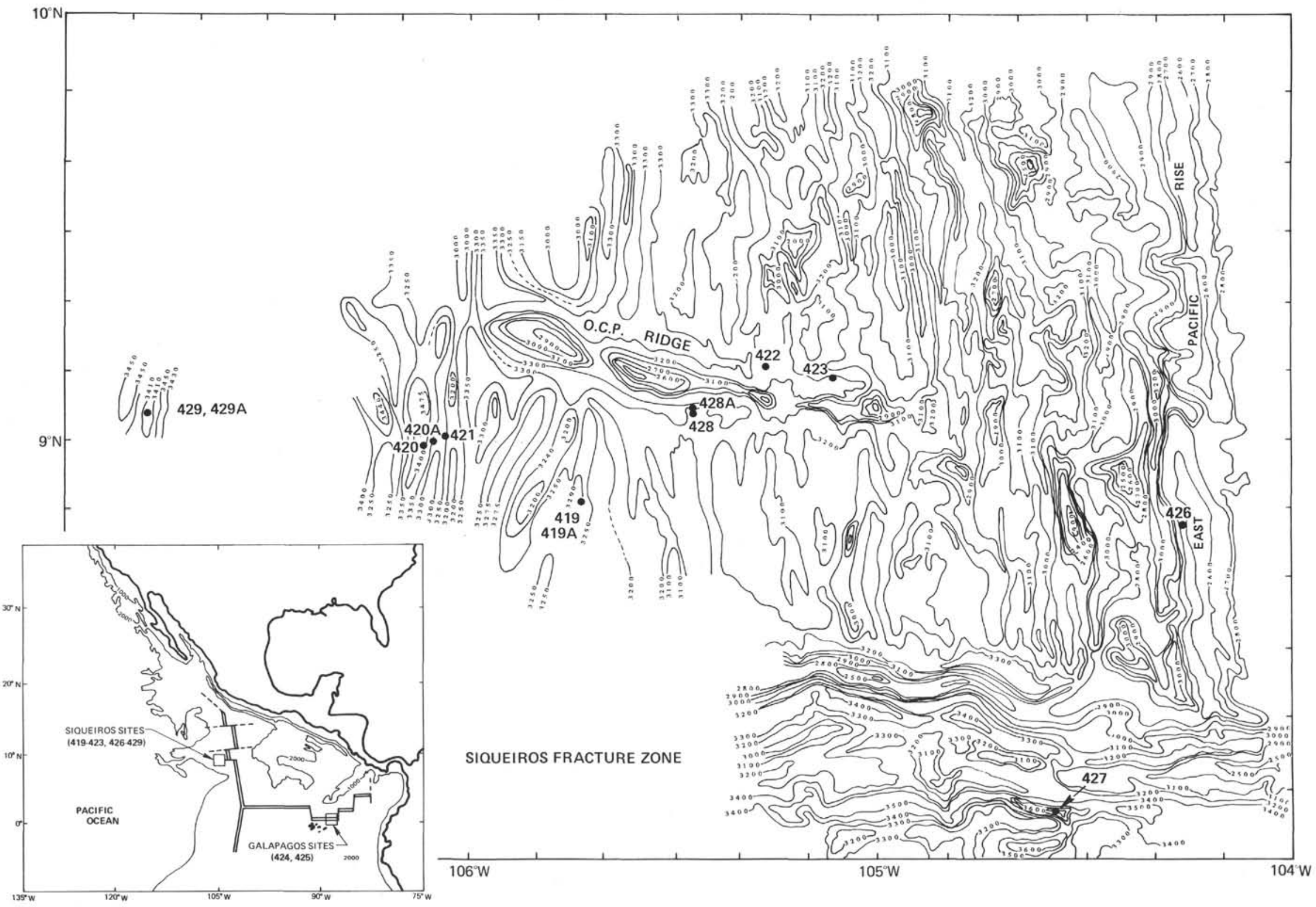

Figure 1. Locations of DSDP Leg 54 Sites 419 through 423 and 426 through 429 on the western flank of the East Pacific Rise; bathymetry in meters. Inset: Location of Galapagos sites on the south flank (Site 424) $20 \mathrm{~km}$ from the crest and on the north flank (Site 425 ) $60 \mathrm{~km}$ from the crest of the Galapagos Rise; bathymetry in fathoms. 


\begin{tabular}{|c|c|c|c|c|c|c|c|c|c|c|c|c|c|}
\hline $\begin{array}{l}\text { SYSTEM AND } \\
\text { SUBSERIES }\end{array}$ & ZONE & SUBZONE & Hol & & Hole 420 & $\begin{array}{l}\text { Hole } \\
421\end{array}$ & $\begin{array}{l}\text { Hole } \\
422\end{array}$ & $\begin{array}{l}\text { Hole } \\
423\end{array}$ & $\begin{array}{l}\text { Hole } \\
424\end{array}$ & $\begin{array}{l}\text { Hole } \\
425\end{array}$ & $\begin{array}{l}\text { Hole } \\
427\end{array}$ & $\begin{array}{l}\text { Hole } \\
428\end{array}$ & $\begin{array}{l}\text { Hole } \\
429\end{array}$ \\
\hline \multirow{5}{*}{ Quaternary } & \multicolumn{2}{|l|}{ Emiliania huxleyi } & & \multirow{2}{*}{$1, \mathrm{CC} / 2-3$} & & \multirow[b]{2}{*}{$1-6$} & \multirow[b]{2}{*}{$1-4 / 3-2$} & \multirow[b]{2}{*}{$1-1 / 2 \cdot 2$} & & & $1-1$ & \multirow[b]{2}{*}{$2-\left.2\right|^{1-4}$} & \\
\hline & \multirow{2}{*}{$\begin{array}{c}\text { Gephyrocapsa } \\
\text { oceanica }\end{array}$} & Ceratolithus cristatus & 3-2/3.CC & & $1-1 / 3-2$ & & & & $2 \cdot-3 / 3 \cdot 3$ & $1-1 / 3-4$ & $2-3$ 3-1? & & \\
\hline & & Emiliania ovata & \multicolumn{2}{|c|}{$4-1 / 4-5$} & $4 \cdot 2 / 7 . \mathrm{CC}$ & & $4-2 / 8-3$ & $3-2 / 5-4$ & $4 \cdot 2 / 4-6$ & $3-6 / 5-4$ & $4-1 / 7-3$ & $3-5$ & \\
\hline & \multirow{2}{*}{$\begin{array}{l}\text { Crenalithus } \\
\text { doronicoides }\end{array}$} & Gephyrocapsa caribbeanica & \multirow{2}{*}{\multicolumn{2}{|c|}{$\frac{5-1}{5-2}$}} & $8 \cdot 2 / 8 . \mathrm{CC}$ & & & & & & \multirow[b]{2}{*}{$8-1 / 8-6$} & $4-5 / 5 \cdot 2$ & \\
\hline & & Emiliania annula & & & $9-4 / 9 . \mathrm{CC} ?$ & & & & & $6-1 / 6-2$ & & & \\
\hline \multirow{4}{*}{$\begin{array}{c}\text { Upper } \\
\text { Pliocene }\end{array}$} & \multirow{4}{*}{$\begin{array}{c}\text { Discoaster } \\
\quad \text { brouweri }\end{array}$} & Cyclococcolithina macintyrei & $5 \cdot 3$ & \multirow{2}{*}{ 5.5? } & $10-2 / 12-4$ & & & & & & & $5-3 / 5-3$ & \\
\hline & & Discoaster pentaradiatus & 5.4 & & 12.CC/13-4 & $2-1$ & & & & & & & $1-1 / 1-2$ \\
\hline & & Discoaster surculus & & & $13-4 / 13-6$ & & & & & & & & $1-3$ \\
\hline & & Discoaster tamalis & & & & & & & & & & & \\
\hline
\end{tabular}

Figure 2. Coccolith zonation of core samples from Leg 54. The numbers assigned to zonal intervals are core and section numbers of samples examined. Where the same zonal interval is represented in two or more core-section samples, the highest and lowest are given, separated by a slash.

TABLE 1

Coccolith Zonation of Basal Sediment Compared with Basalt Magnetic Age Estimates

\begin{tabular}{lllccccc}
\hline & $\begin{array}{c}\text { Series } \\
\text { or }\end{array}$ & $\begin{array}{c}\text { Coccolith Zone } \\
\text { or Subzone }\end{array}$ & $\begin{array}{c}\text { Sediment } \\
\text { Depth }(\mathrm{m})\end{array}$ & $\begin{array}{c}\text { Basalt } \\
\text { Depth (m) }\end{array}$ & $\begin{array}{c}\text { Magnetic } \\
\text { Age } \\
\text { Estimate } \\
\text { (m.y.) }\end{array}$ & $\begin{array}{c}\text { Series } \\
\text { or } \\
\text { Subseries }\end{array}$ & $\begin{array}{c}\text { Coccolith/ } \\
\text { Magnetic } \\
\text { Agreement }\end{array}$ \\
\hline 423 & Upper Quaternary & E. ovata & 37.7 & 41.5 & 1.6 & Lower Quaternary & X \\
422 & Upper Quaternary & E. ovata & 52.5 & 53.2 & 1.79 & Lower Quaternary & X \\
428 & Upper Pliocene & C. macintyrei & 61.3 & 62.0 & $2.0-2.5$ & Upper Pliocene & $\checkmark$ \\
419 & Upper Pliocene & D. pentaradiatus & 35.0 & (not reached) & $2.43-2.93$ & Upper Pliocene & $\checkmark$ \\
421 & Upper Pliocene & D. pentaradiatus & 85.6 & 85.6 & 3.37 & Lower Pliocene & X \\
420 & Upper Pliocene & D. surculus & 116.9 & 118.0 & 3.37 & Lower Pliocene & X \\
429 & Upper Pliocene & D. surculus & 4.3 & (not reached) & 4.6 & Lower Pliocene & X \\
427 & Lower Quaternary & C. doronicoides & 126.2 & 136.0 & 3.3 & Lower Pliocene & X \\
424 & Upper Quaternary & E. ovata & 36.7 & 36.9 & 0.69 & Upper Quaternary & $\checkmark$ \\
425 & Lower Quaternary & E. annula & 74.7 & 81.5 & 1.8 & Lower Quaternary & $\checkmark$ \\
\hline
\end{tabular}

Note: Coccolith zones are all younger than, or coeval with, basalt ages. Sites 423 through 429 are arrayed in a transect just north of the Siqueiros fracture zone, with Site 423 close to the East Pacific Rise crest. Site 427 is within the fracture zone. Sites 424 and 425 are far to the southeast near the Galapagos Islands. Magnetic age estimates are by shipboard scientists and based on anomaly pattern and distance from spreading center.

photic zone (Beers and Stewart, 1971; Bukry, 1973). This situation suggests a degree of caution for the direct application of $C$. pelagicus to paleolatitudinal reconstructions. The distribution emphasizes, again, that watermass characteristics are most important to a given species than any prescribed latitudes (Burns, 1972; Bukry, 1978). C. pelagicus would be valuable, however, for monitoring changes of watermasses through a region.

\section{SITE SUMMARIES OF THE SIQUEIROS FRACTURE ZONE AND GALAPAGOS AREAS}

All eight sites cored near the junction of the Siqueiros fracture zone and East Pacific Rise crest on Leg 54 were intended to study young igneous oceanic crust in an area of a fast-spreading ridge. Therefore, the sediment cores of upper Pliocene and Quaternary calcareous and siliceous biogenic oozes were recovered incidentally to the primary basalt coring. Although there were no biostratigraphic and paleoecologic objectives in the sediment coring, the microfossil assemblages of the cores provide a useful reference for latitudinal studies of the eastern tropical Pacific. Galapagos Sites 424 and 425 are just north and south of the crest of the Galapagos spreading center, respectively.

\section{Site 419 \\ $\left(08^{\circ} 55.96^{\prime} \mathrm{N}, 105^{\circ} 41.17^{\prime} \mathrm{W}\right.$, depth $\left.3274 \mathrm{~m}\right)$}

Coccoliths in the five continuously cut sediment cores of Hole 419 range from the upper Pliocene Discoaster pentaradiatus Zone at 35 meters sub-bottom to the upper Quaternary Ceratolithus cristatus Subzone or Emiliania huxleyi Zone at 0 meters. The coccoliths are generally well preserved with only slight to moderate etching which is most pronounced in Sample 419-4-3. 127$129 \mathrm{~cm}(24 \mathrm{~m})$. Abundant discoasters in the Pliocene and abundant gephyrocapsids in the Quaternary indicate generally warm conditions.

The upper Pliocene Discoaster pentaradiatus Zone of Core 5 is identified by the presence of rare to few Discoaster asymmetricus and $D$. pentaradiatus, common to abundant $D$. brouweri, and a lack of $D$. surculus and $D$. tamalis. The boundary between the Cyclococcolithina macintyrei Subzone and Emiliania annula Subzone, approximating the Pliocene/Quaternary boundary, is identified between 32 and 33 meters in upper Core 5 by a dramatic reduction in discoaster numbers. A coincident increase in abundance of Coccolithus pelagicus and Helicosphaera sellii is reminiscent of essentially coeval 


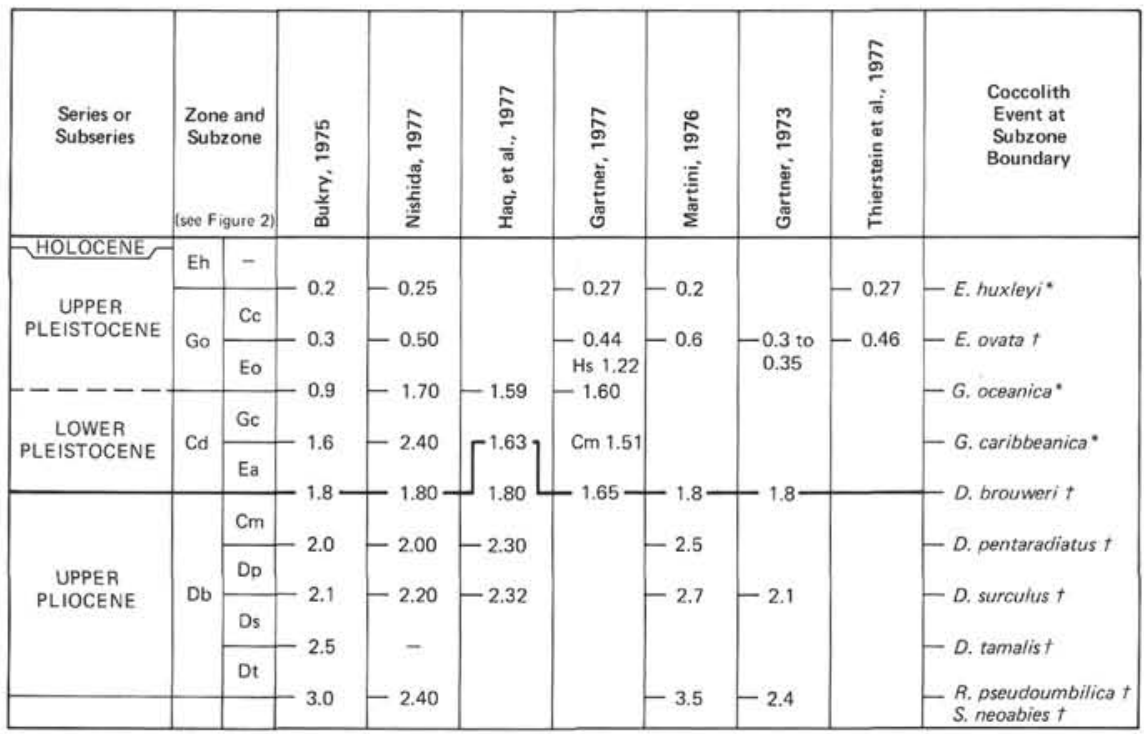

Figure 3. Ages assigned to appearances and disappearances of coccolith species commonly used for upper Pliocene and Pleistocene biostratigraphy, correlated to the zonal sequence of Bukry (1975). Heavy line atop upper Pliocene represents the Pliocene/Pleistocene boundary relative to biostratigraphic boundaries. $\mathrm{Cm}=$ Cyclococcolithina macintyrei extinction, $\mathrm{Hs}=$ Helicosphaera sellii extinction.

assemblages from high-latitude areas as far away as the North Atlantic (Bukry, 1972) and emphasizes a widespread change in plankton ecology at the boundary interval (Figure 6).

Sample 419-4-3, 127-129 cm (24 m), noted for moderate dissolution, is also notable for lying within the Gephyrocapsa oceanica Zone (Boudreaux and Hay, 1967; Bukry, 1975) but lacking Gephyrocapsa. Because the central area bars of Gephyrocapsa are relatively resistant to dissolution, some specimens retain their identity even in more strongly dissolved assemblages. Therefore, this sample level may be correlative with the socalled "Small Gephyrocapsa Zone" occurring from 1.22 to 0.92 m.y. ago (Gartner, 1977). This correlation is supported by the disappearance of $\mathrm{H}$. sellii in Core 5 and by the acme peak of the silicoflagellate Mesocena quadrangula in Core 4. The M. quadrangula acme (1.30 to 0.79 m.y., Burckle, $1977 ; 1.40$ to 0.60 m.y., Jousé and Mukhina, 1973) and peak interval $(0.85$ to 0.95 m.y., Jousé and Mukhina, 1973) suggest a correlation near 0.95 m.y., which matches the level for this sample on the Site 419 sedimentation curve generated by coccolith, diatom, radiolarian, and silicoflagellate data for low latitude. The absence of large gephyrocapsids suggests a short-term cooling. Typical Gephyrocapsa oceanica is abundant through the upper three cores.

\section{Site 420 \\ $\left(09^{\circ} 00.10^{\prime} \mathrm{N}, 106^{\circ} 06.77^{\prime} \mathrm{W}\right.$, depth $\left.3381 \mathrm{~m}\right)$}

Upper Pliocene Discoaster surculus Subzone to upper Quaternary Ceratolithus cristatus Subzone coccoliths are abundant and moderately to strongly etched in continuously cut Cores 1 through 13 ( 0 to $119 \mathrm{~m})$. Discoas- ter assemblages in Cores 10 through 13 are dominated by Discoaster brouweri; the only other abundant species is $D$. pentaradiatus in Sections 420-13-5 and 420-13-6 (Figure 7). The abundance of discoasters gradually declines uphole to the point in Section 420-10-4 where discoasters are sparse and fall to $\leq 1$ per cent. In Section $420-10-2$ the decline of both $D$. brouweri $(0.3 \%)$ and Cyclococcolithina macintyrei $(0.7 \%)$ suggests proximity to the Pliocene/Pleistocene boundary. Correlation of Core 9 samples is problematic since both guide species show increased abundances, but small Gephyrocapsa sinuosa is also present suggesting basal Quaternary. Dissolution is strong. More detailed sampling in the boundary interval of Cores 9 and $10(71$ to $90 \mathrm{~m})$ is needed to establish coccolith distribution and to study reworking and dissolution patterns.

Site 421

$\left(09^{\circ} 01.41^{\prime} \mathrm{N}, 106^{\circ} 03.68^{\prime} \mathrm{W}\right.$, depth $\left.3339 \mathrm{~m}\right)$

Coccoliths occur in two cores only. The small amount of sediment recovered immediately above basalt in Sample 421-2-1, 3-5 cm (86 m) contains abundant. moderately etched coccoliths of the upper Pliocene Discoaster pentaradiatus Subzone with sparse downhole contaminants from the Quaternary Emiliania ovata Subzone. Discoaster brouweri is abundant, $D$. pentaradiatus sparse, and contaminants (such as Gephyrocapsa oceanica and $G$. omega) are sparse.

Sample 421-1-6, 128-130 cm (8 m) contains a lowdiversity assemblage, including Crenalithus productellus, Cyclococcolithina leptopora, and Gephyrocapsa oceanica, which is correlated to the Ceratolithus cristatus Subzone or Emiliania huxleyi Zone. 


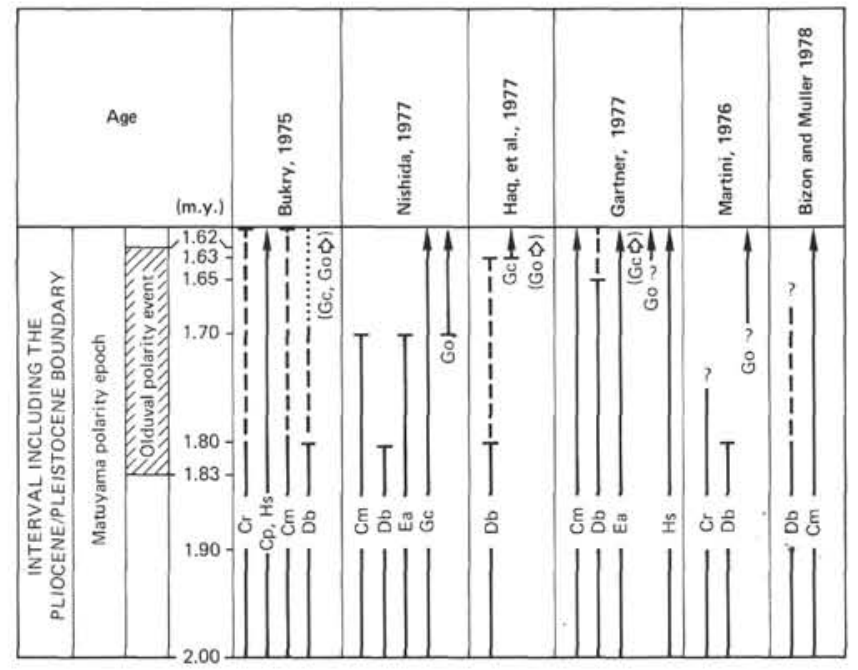

Figure 4. Relative and absolute ranges of coccolith biostratigraphic guide species in the interval (1.60 to 2.00 m.y.) which includes the Pliocene/Pleistocene boundary. Magnetic register based on LaBrecque et al. (1977). Dashed line signifies sparse, sporadic, possibly reworked ranges. Solid arrows show range continuing beyond 1.6 m.y. Open arrows in parentheses show species appearing at or just beyond 1.6 m.y. Coccolith species abbreviations: $\mathrm{Cr}=$ Ceratolithus rugosus, $C p=$ Coccolithus pelagicus, $\mathrm{Cm}=$ Cyclococcolithina macintyrei, $D b=$ Discoaster brouweri, $E a=$ Emiliania annula, $G c=$ Gephyrocapsa caribbeanica, $G o=$ Gephyrocapsa oceanica, $H s=$ Helicosphaera sellii. Bukry (1975), Martini (1976), and Nishida (1977) used the last common or consistent occurrences of Discoaster (at $\sim 1.8$ m.y.) to correlate the Pliocene/Pleistocene boundary. Gartner (1977) used the same biostratigraphic event but assigned a younger (1.65 m.y.) age near the end of the Olduvai polarity event, instead of near its beginning. Haq et al. (1977) used the end of the Olduvai or a slightly later ( 1.6 m.y.) time for the boundary, identifying it between the first appearances of Gc and Go. Bizon and Müller (1978) chose an even younger level, the extinction of Cm $(1.51$ m.y., according to Gartner, 1977), to correlate the boundary. Therefore, the interval between the disappearances of $D b$ and $\mathrm{Cm}$ contains the Pliocene/Pleistocene boundary for coccoliths (1.51 to 1.8 m.y.).

\section{Site 422}

$\left(09^{\circ} 10.59^{\prime} \mathrm{N}, 105^{\circ} 16.27^{\prime} \mathrm{W}\right.$, depth $\left.3247 \mathrm{~m}\right)$

Upper Quaternary coccoliths in the seven continuously cut sediment cores from Hole 422 are moderately to poorly preserved because of dissolution. The sedimentary section is interrupted by a doleritic basalt unit in Core 7 (45 to $49 \mathrm{~m}$ ), which was assigned to the upper part of the Matuyama polarity epoch by shipboard scientists. The coccoliths in Core 8 include sparse $\mathrm{Ge}$ phyrocapsa oceanica, sparse Cyclococcolithina macintyrei, and Discoaster brouweri which are probably reworked. Reworking is suggested by the high abun-

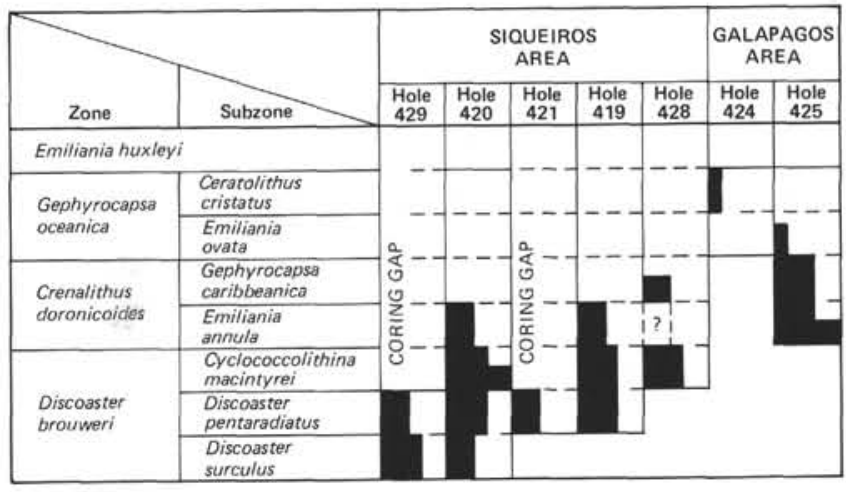

Figure 5. Range and abundance of Coccolithus pelagicus at Leg 54 sites. Rare, few, common, and abundant shown by four bar thickness increments. Abundant $\mathrm{C}$. pelagicus reflects a cool watermass or $a$ related environmental factor.

dance $(58 \%$ and $65 \%)$ of Mesocena quadrangula in Core 8 , identifying the silicoflagellate Mesocena quadrangula Zone, which has its peak abundance near the Jaramillo polarity event of the late Matuyama (Hays et al., 1969).

Gephyrocapsa oceanica and Emiliania annula occur above in Cores 4 and 5, showing that the lower Gephyrocapsa oceanica Zone occurs above and below the basaltic rock unit. G. oceanica increases in abundance uphole through Core 4, and, except for Sample 422-3-2, $125-126 \mathrm{~cm}(20 \mathrm{~m})$, is abundant in Cores 1 through 3. This increase in large gephyrocapsids at Site 422 coincides with the sparseness or absence of silicoflagellates above Core 4. Poorly preserved Sample 422-3-2, $125-126 \mathrm{~cm}(20 \mathrm{~m})$, although within the range of abundant Gephyrocapsa oceanica, lacks this species. Correlation to the "Small Gephyrocapsa Zone" might be suggested, but the 0.3 to $0.6 \mathrm{~m}$.y. age, estimated by the sedimentation curves, differs too much from the 0.9 to 1.2 m.y. age for that zone (Gartner, 1977). Detailed sampling, beyond the scope of this initial report, is needed to establish the ecologic and biostratigraphic correlation of fluctuations in species abundance.

\section{Site 423 \\ $\left(09^{\circ} 08.81^{\prime} \mathrm{N}, 105^{\circ} 06.57^{\prime} \mathrm{W}\right.$, depth $\left.3161 \mathrm{~m}\right)$}

Quaternary coccoliths are common or abundant, and moderately etched in the five continuously cut sediment cores from Hole 423, which was drilled on crust presumed to be part of the late Matuyama polarity epoch. Gephyrocapsa oceanica is common in all but the basal sediment samples, Samples 423-5-4, 70-71 cm and 423$75-77 \mathrm{~cm} \mathrm{(42} \mathrm{m);} \mathrm{Cyclococcolithina} \mathrm{leptopora} \mathrm{is} \mathrm{com-}$ mon throughout. The absence of $G$. oceanica could signify the Crenalithus doronicoides Zone or "Small $\mathrm{Ge}$ phyrocapsa Zone," because Cyclococcolithina macintyrei and Helicosphaera sellii are missing. Either correlation would be in approximate agreement with the magnetic model. The tenuous sedimentation curve for Site 423 , based on three radiolarian and coccolith data 


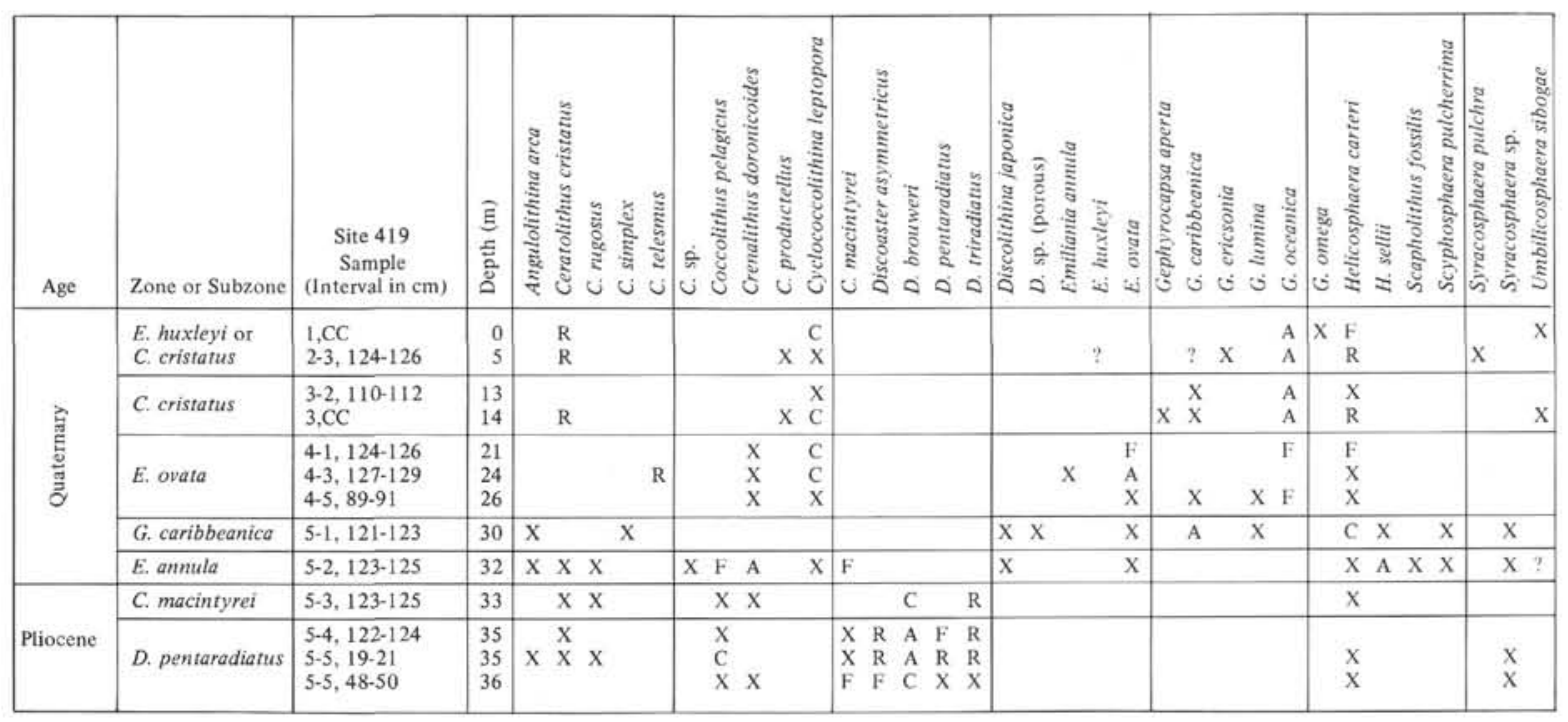

Figure 6. Occurences of coccoliths at Site 419 based on preliminary light-microscope studies. Relative abundance estimates indicated by $A, C, F$, and $R . X=$ present. ? = questionably identified.

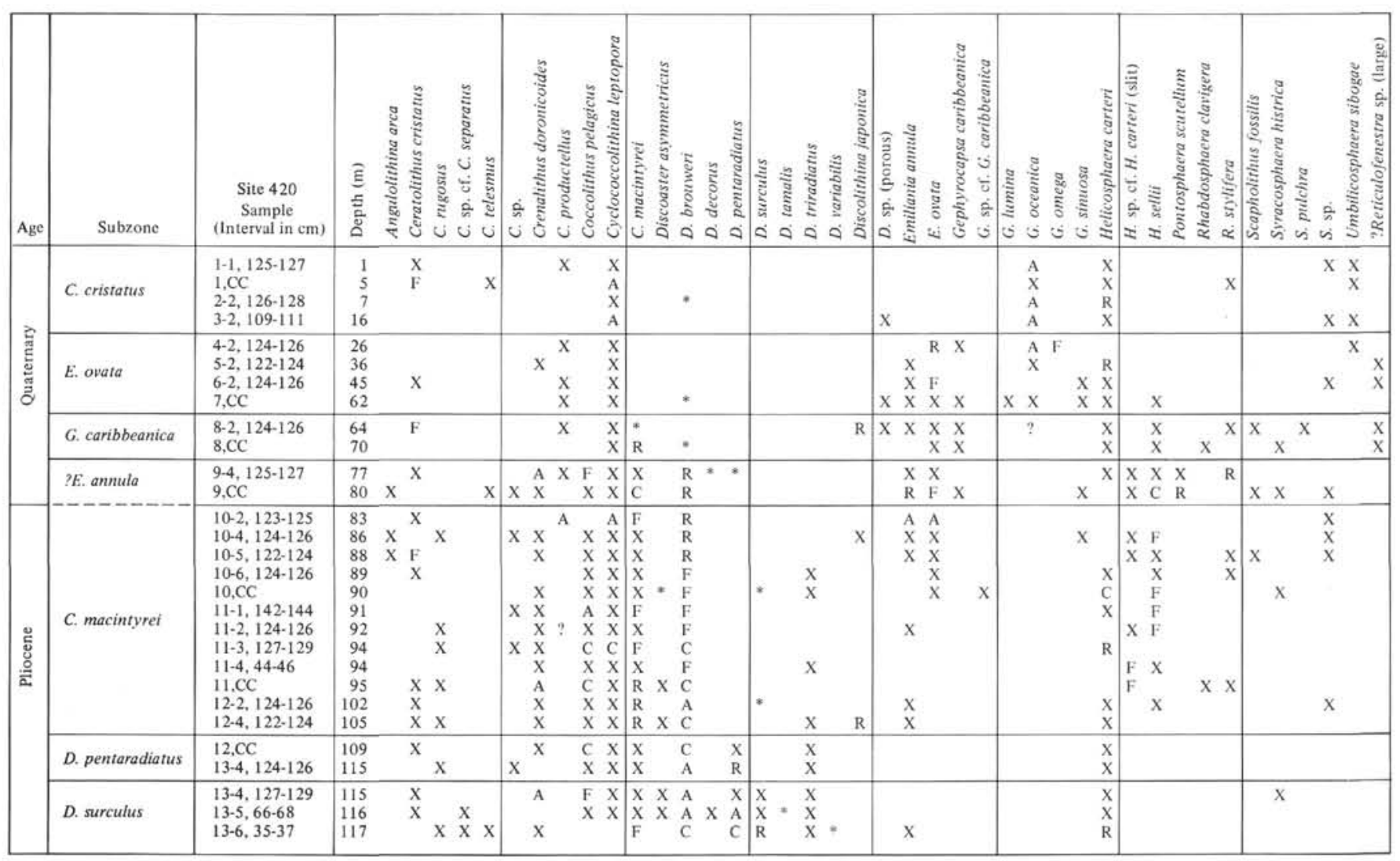

Figure 7. Occurrences of coccoliths at Site 420 based on preliminary light-microscope studies. Abundances indicated by $A, C, F, R . X=$ present. ? = questionably identified. * = reworked. 
points, indicates an approximate 1.0 m.y. age, favoring a "Small Gephyrocapsa Zone" (Gartner, 1977) correlation for Samples 423-5-4, 70-71 cm and 423-5-4, 75-77 $\mathrm{cm}(42 \mathrm{~m})$.

\section{Site 424 \\ $\left(00^{\circ} 35.33-.93^{\prime} \mathrm{N}, 8^{\circ} 07.81-.82^{\prime} \mathrm{W}\right.$, depth 2685-2708 m)}

Several holes were drilled at Site 424 in a local area of hydrothermal mounds on the sea floor northeast of the Galapagos Islands. Of the 13 samples examined from these holes, 10 contain abundant, well-preserved coccoliths (all upper Quaternary) with only slight etchings so that central bars are intact and margins are not incised. Two barren samples, Samples 424-2-1, 80-82 cm (10 m) and 424B-2-3, 120-122 cm $(8 \mathrm{~m})$, are from the nearsurface hydrothermal deposits. The deposits at both these holes and at Hole 424A are above the extinction level of Emiliania ovata and are therefore younger than 0.46 m.y. (Thierstein et al., 1977).

Gephyrocapsa spp. are common to abundant in all of the assemblages, except Sample 424A-3-3, 95-97 cm (29 $\mathrm{m})$. Small Crenalithus productellus are especially abundant in Samples 424-4-2, 81-82 cm (31 m), 424A-3-3, $95-97 \mathrm{~cm}(29 \mathrm{~m})$, and 424B-4-4, 80-82 cm $(28 \mathrm{~m})$, suggesting correlation and similar rates of deposition between Holes 424 and 424B. The highest Emiliania ovata in Samples 424-4-2, 81-82 cm (31 m) and 424B-4-4, $80-82 \mathrm{~cm}(28 \mathrm{~m})$ also supports this correlation.

The definite presence of Emiliania huxleyi, first occurring at $0.27 \mathrm{~m} . y$. (Thierstein et al., 1977), has not been determined for Site 424 , as no SEM studies were done.

\section{Site 425 \\ $\left(01^{\circ} 23.68^{\prime} \mathrm{N}, 86^{\circ} 04.22^{\prime} \mathrm{W}\right.$, depth $\left.2850 \mathrm{~m}\right)$}

Coccoliths are only slightly etched in Cores 1 through 5. Dissolution is moderate in Core 6 and the preservation of reworked discoasters is variable, both etched and overgrown. Coccoliths are abundant through the section, which is incomplete owing to a skip-coring program which created gaps of 9.5 meters between Cores 2 and 3,3 and 4 , and 4 and 5 .

There are abundant Gephyrocapsa oceanica with low angle bars, and few $G$. omega, indicating warm-water conditions for the assemblages that bracket the upper boundary of the Emiliania ovata Subzone, Samples $425-3-4,120-121 \mathrm{~cm}(30 \mathrm{~m})$ and $425-3-6,120-121(33 \mathrm{~m})$. (33 m).

Core 6 samples are assigned to the Emiliania annula Subzone of the basal Quaternary on the basis of common Coccolithus pelagicus, Cyclococcolithina macintyrei, and sparse Gephyrocapsa sinuosa, but no $G$. caribbeanica or $G$. oceanica. The sparseness, high diversity, and species composition show that the associated discoaster assemblage is reworked. Discoaster brouweri does not dominate the older species which became extinct through the uppermost Miocene and Pliocene -
Discoaster berggrenii, $D$. pentaradiatus, $D$. quinqueramus, D. surculus, D. tamalis, and D. variabilis.

A dramatic reduction in the abundance of Coccolithus pelagicus, upsection, between Cores 5 and 6 occurs with a matching reduction in abundance of the silicoflagellate Distephanus speculum, indicating a distinct warming during that interval. A further warming is suggested in the lower sections of Core 3 by the increased abundance of Dictyocha and the decrease of Mesocena. Coccolith evidence at this level, including diverse $G e$ phyrocapsa, Scapholithus fossilis s. ampl., Discolithina sp., and Rhabdosphaera stylifera, suggests less dissolution and warmer conditions. Also, the increased abundance of Gephyrocapsa at this level persists uphole and contrasts with the lower abundances in deeper levels.

\section{Site $\mathbf{4 2 6}$ \\ $\left(08^{\circ} 47.28^{\prime} \mathrm{N}, 104^{\circ} 15.27^{\prime} \mathrm{W}\right.$, depth $\left.2617-2632 \mathrm{~m}\right)$}

No coring was attempted at Site 426 on the axial block of the East Pacific Rise, because no sediment pocket thicker than 10 meters could be found to spud-in the drill string.

Site 427

$\left(08^{\circ} 06.79^{\prime} \mathrm{N}, 104^{\circ} 36.35^{\prime} \mathrm{W}\right.$, depth $\left.3834 \mathrm{~m}\right)$

Coccoliths are common to abundant and moderately to strongly etched in the expanded Quaternary section of Hole 427, drilled in the Siqueiros fracture zone. The deep water at Hole 427 , and the generally low diversity of the coccolith assemblages, suggest possible removal by dissolution or even exclusion of some taxa, such as Helicosphaera, by competition from other phytoplankton for nutrients by periodic blooms (Ethmodiscus rex oozes occur). Gephyrocapsa is sparse and sporadic in Core 8 at the base of the sediment section, and Coccolithus pelagicus, Cyclococcolithina macintyrei, and Helicosphaera sellii are absent or sparse, suggesting correlation to the Crenalithus doronicoides Zone, probably the upper part. Poor preservation has increased the relative abundance of dissolution-resistant Cyclococcolithina leptopora in this and higher cores.

\section{Site 428 \\ $\left(09^{\circ} 02.77^{\prime} \mathrm{N}, 105^{\circ} 26.14^{\prime} \mathrm{W}\right.$, depth $\left.3295 \mathrm{~m}\right)$}

The upper Pliocene and Quaternary coccoliths of Site 428 are slightly to moderately etched and diverse. The assemblages of the Discoaster brouweri Zone and Crenalithus doronicoides Zone (Cores 4 and 5) are distinctive in the very common to abundant occurrence of Helicosphaera sellii (Figure 8). Although $H$. sellii is few to common in abundance at Sites 419 and 420 , this species is missing in coeval samples at nearby Site 427 .

The Pliocene/Pleistocene boundary is indicated by the presence of a few small Discoaster brouweri and $D$. triradiatus in Samples 428-5-3, 77-79 cm $(61 \mathrm{~m})$ and $428-5-3,46-47 \mathrm{~cm}$ (61 m). Sample 428-5-2, 120-121 cm $(60 \mathrm{~m})$ contains only sparse $D$. brouweri fragments, but has the first sparse Gephyrocapsa sp. cf. G. caribbeani$c a$ and $G$. sinuosa and is assigned to Quaternary. 


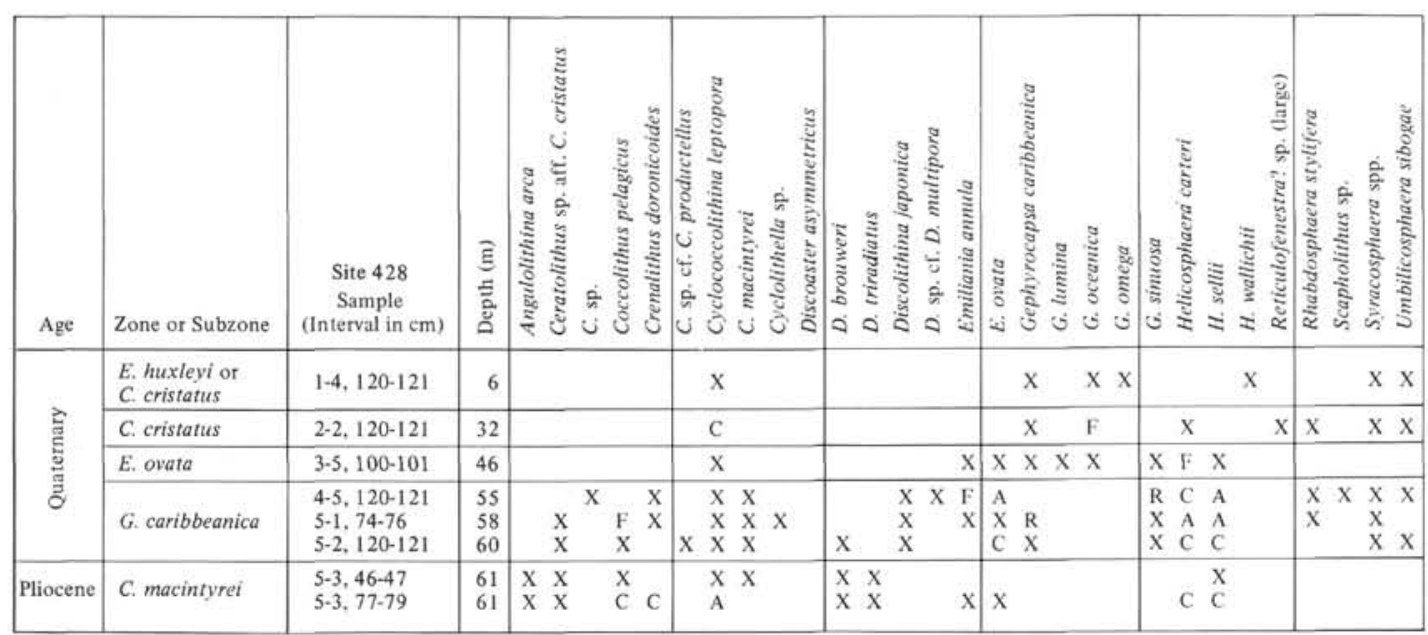

Figure 8. Occurrences of coccoliths at Site 428 based on preliminary light-microscope studies. Relative abundance estimates indicated by $\mathrm{A}, \mathrm{C}, \mathrm{F}$, and $\mathrm{R} . \mathrm{X}=$ present.

\section{Site 429}

\section{$\left(09^{\circ} 02.01\right.$ ' $\mathrm{N}, 106^{\circ} 46.35^{\prime} \mathrm{W}$, depth $\left.3406 \mathrm{~m}\right)$}

Upper Pliocene discoaster-rich assemblages characterize the single sediment core recovered at Site 429. A census of 300 discoasters in the deepest sample, Sample 429-1-3, 130-131 cm (4 m), shows 66 per cent Discoaster brouweri, 31 per cent $D$. pentaradiatus, 1 per cent $D$. surculus, and 1 per cent $D$. blackstockae. Also sparsely present are $D$. asymmetricus, $D$. quadramus, $D$. tamalis (reworked?), and $D$. triradiatus. Dissolution is slight to moderate but the individual rays of disaggregated discoasters are abundant. Because of the scarcity and absence of $D$. surculus in the upper part of the core, only the lowest sample is assigned to the upper Discoaster surculus Subzone.

Although the diverse assemblages contain Angulolithina, Ceratolithus, Helicosphaera, and Syracosphaera, many solution-susceptible, low-latitude taxa were not observed, including Discolithina, Hayaster, Oolithotus, Rhabdosphaera, Scapholithus, and Scyphosphaera.

\section{ACKNOWLEDGMENT}

I thank R. Z. Poore and J. A. Barron, U.S. Geological Survey, for their comments and constructive criticisms of this paper. Study of Leg 54 core samples was made possible through the courtesy of Roger Hekinian and B. R. Rosendahl, Co-Chief Scientists, and James Natland, DSDP Staff Scientist for Leg 54.

\section{REFERENCES}

Beers, J. R. and Stewart, G. L., 1971. Micro-zooplankters in the plankton communities of the upper waters of the eastern tropical Pacific, Deep-Sea Research, v. 18, p. 861-883.

Bizon, G. and Müller, C., 1978. Remarks on the determination of the Pliocene-Pleistocene boundary in the Mediterranean. In Hsü, K. J., Montadert, L., et al., Initial Reports of the Deep Sea Drilling Project, v. 42, Part 1: Washington (U.S. Government Printing Office), p. 847-853.

Boudreaux, J. E. and Hay, W. W., 1967. Zonation of the latest Pliocene-Recent interval, Gulf Coast Association of Geological Societies Transactions, v. 17, p. 443-445.
Bukry, D., 1971. Coccolith stratigraphy Leg 7, Deep Sea Drilling Project. In Winterer, E. L., Riedel, W. R., et al., Initial Reports of the Deep Sea Drilling Project, v. 7, Part 2, Washington (U.S. Government Printing Office), p. 15131528.

1972. Further comments on coccolith stratigraphy, Leg 12, Deep Sea Drilling Project. In Laughton, A. S., Berggren, W. A., et al., Initial Reports of the Deep Sea Drilling Project, v. 12: Washington (U.S. Government Printing Office), p. 1071-1083.

1973. Coccolith stratigraphy, eastern equatorial $\mathrm{Pa}-$ cific, Leg 16 Deep Sea Drilling Project. In van Andel, Tj. H., Heath, G. R., et al., Initial Reports of the Deep Sea Drilling Project, v. 16: Washington (U.S. Government Printing Office), p. 653-711.

1974. Coccolith stratigraphy, offshore western Australia, Deep Sea Drilling Project Leg 27. In Veevers, J. J., Heirtzler, J. R., et al., Initial Reports of the Deep Sea Drilling Project, v. 27: Washington (U.S. Government Printing Office), p. 623-630.

1975. Coccolith and silicoflagellate stratigraphy, northwestern Pacific Ocean, Deep Sea Drilling Project Leg 32. In Larson, R. L., Moberly, R., et al., Initial Reports of the Deep Sea Drilling Project, v. 32: Washington (U.S. Government Printing Office), p. 677-701.

1976. Silicoflagellate and coccolith stratigraphy, southeastern Pacific Ocean, Deep Sea Drilling Project Leg 34, In Yeats, R. S., Hart, S. R., et al., Initial Reports of the Deep Sea Drilling Project, v. 34: Washington (U.S. Government Printing Office), p. 715-735.

1978. Biostratigraphy of Cenozoic marine sediment by calcareous nannofossils, Micropaleontology, v. 24, no. 1, p. 44-60.

Bukry, D. and Bramlette, M. N., 1969. Some new and stratigraphically useful calcareous nannofossils of the Cenozoic, Tulane Studies in Geology and Paleontology, v. 7, p. 131-142.

Bukry, D. and Foster, J. H., 1973. Silicoflagellate and diatom stratigraphy, Leg 16, Deep Sea Drilling Project. In van Andel, Tj. H., Heath, G. R., et al., Initial Reports of the Deep Sea Drilling Project, v. 16: Washington (U.S. Government Printing Office), p. 815-871. 
Burckle, L. H., 1977. Pliocene and Pleistocene diatom datum levels from the equatorial Pacific, Quaternary Research, v. 7, p. 330-340.

Burns, D. A., 1972. The latitudinal distribution and significance of calcareous nannofossils in the bottom sediments of the south-west Pacific Ocean (lat. 15-55 ${ }^{\circ} \mathrm{S}$ ) around New Zealand. In Oceanography of the South Pacific 1972: Wellington (New Zealand National Commission for UNESCO), p. 221-228.

Gartner, S., 1973. Absolute chronology of the late Neogene calcareous nannofossil succession in the equatorial Pacific, Geological Society of America Bulletin, v. 84, p. 20212034.

1977. Calcareous nannofossil biostratigraphy and revised zonation of the Pleistocene, Marine Micropaleontology, v. 2, p. 1-25.

Haq, B. U., Berggren, W. A., and Van Couvering, J. A., 1977. Corrected age of the Pliocene/Pleistocene boundary, Nature, v. 269, p. 483-488.

Hay, W. W. and Beaudry, F. M., 1973. Calcareous nannofossils - Leg 15, Deep Sea Drilling Project. In Edgar, N. T., Saunders, J. B., et al., Initial Reports of the Deep Sea Drilling Project, v. 15: Washington (U.S. Government Printing Office), p. 625-683.

Hays, J. D., Saito, T., Opdyke, N. D., and Burckle, L. H., 1969. Pliocene-Pleistocene sediments of the equatorial $\mathrm{Pa}$ - cific: their paleomagnetic, biostratigraphic, and climatic record, Geological Society of America Bulletin, v. 80. p. 1481-1514.

Jousé, A. P. and Mukhina, V. V., 1973. The Mesocena elliptica Ehr. Zone in the Pleistocene sediments of the Pacific Ocean, Oceanology (AGU Translation), v. 13, p. 386-394.

LaBrecque, J. L., Kent, D. V., and Cande, S. C., 1977. Revised magnetic polarity time scale for Late Cretaceous and Cenozoic time, Geology, v. 5, p. 330-335.

Martini, E., 1976. Neogene and Quaternary silicoflagellates from the central Pacific Ocean (DSDP Leg 33). In Schlanger, S. O., Jackson, E. D., et al., Initial Reports of the Deep Sea Drilling Project, v. 33: Washington (U.S. Government Printing Office), p. 439-449.

McIntyre, A., Bé, A. W. H., and Roche, M. B., 1970. Modern Pacific Coccolithophorida: A paleontological thermometer, New York Academy of Sciences Transactions, v. 32, p. 720-731.

Nishida, S., 1977. Late Cenozoic calcareous nannoplankton biostratigraphy in Japan (abstract), First International Congress on Pacific Neogene Stratigraphy Proceedings: Tokyo, p. 376-378.

Thierstein, H. R., Geitzenauer, K. R., Molfino, B., and Shackleton, N. J., 1977. Global synchroneity of late Quaternary coccolith datum levels: Validation by oxygen isotopes, Geology, v. 5, p. 400-404. 